\title{
Analisis Kandungan Logam Merkuri pada Kerang Kepah (Polymesoda erosa) di SUB DAS Batanghari Hilir Kota Jambi
}

\author{
Wasibar Gerit Ario Putra ${ }^{1}$, Jalius ${ }^{2}$, dan Shally Yanova ${ }^{3}$ \\ 1,2,3 Teknik Lingkungan, Universitas Jambi, Jambi, Indonesia \\ Email: iamgeritweird@gmail.com, jaliusc5112@gmail.com, shallyyanova@unja.ac.id
}

\section{Info Artikel}

Diterima: 13 Agustus 2021

Disetujui: 27 Agustus 2021

Dipublikasikan: 31 Agustus 2021

Alamat Korespondensi:

iamgeritweird@gmail.com

Copyright (c) 2021 Jurnal

Engineering

This work is licensed under the Creative Commons Attribution International License (CC BY $4.0)$.

\begin{abstract}
Abstrak
Masyarakat yang memiliki tingkat kesadaran yang rendah akan pentingnya menjaga kebersihan dan kelestarian lingkungan menyebabkan sungai menjadi tempat pembuangan limbah. Limbah yang mencemari sungai akan merugikan makhluk hidup yang ada di sungai maupun di sekitar sungai tersebut, contoh makhluk hidup yang ada di sungai yaitu kerang kepah. Kerang adalah salah satu biota air yang dapat dijadikan indikator tingkat pencemaran yang terjadi di dalam perairan. Kerang bersifat filter feeder, yang mendapatkan makanannya dengan cara menyaring air, dan memakan sedimen sehingga dapat mengakumulasi logam berat dalam jumlah yang tinggi, terutama logam merkuri (Hg). Dengan adanya resiko pencemaran pada kerang kepah oleh logam berat terutama Merkuri yang dapat membahayakan bagi manusia jika mengkonsumsi kerang tersebut, maka perlu dilakukan penelitian terhadap kandungan Merkuri ( $\mathrm{Hg}$ ) pada kerang kepah secara Inductively Coupled Plasma (ICP). Kerang kepah yang digunakan diambil dari perairan Sungai Batanghari sekitar Jembatan Aurduri 1 dan Jembatan Aurduri 2. Menggunakan metode Inductively Coupled Plasma (ICP) karena metode ini merupakam sebuah teknis analisis yang digunakan untuk deteksi dari trace metals dalam sampel lingkungan pada umumnya.
\end{abstract}

Kata kunci: Destruksi Basah; Inductively Coupled Plasma (ICP); Kerang Kepah; Merkuri (Hg).

\section{Pendahuluan}

Masyarakat yang memiliki tingkat kesadaran yang rendah akan pentingnya menjaga kebersihan dan kelestarian lingkungan menyebabkan sungai menjadi tempat pembuangan limbah domestik ataupun non domestik, contohnya membuang air besar dan kecil, pembuangan limbah dari kegiatan pertanian yaitu pestisida. Limbah yang mencemari sungai akan merugikan makhluk hidup yang ada di sungai maupun di sekitar sungai tersebut. Salah satu jenis bahan pencemar yang akan mencemari sungai yaitu logam berat, dimana sumber utamanya adalah dari limbah industri (Dewi,2009). 
Menurut Ratnaningsih (2019), mengatakan bahwa hasil dalam penelitiannya mengidentifikasikan adanya distribusi merkuri baik di air sungai maupun sedimen di Sungai Batanghari. Merkuri di air Sungai Batanghari berfluktuasi pada kisaran $<0,0005-0,0645 \mathrm{mg} / \mathrm{L}$, sedangkan pada sedimen Sungai Batanghari terdeteksi dengan kisaran 0,01 - 0,42 mg/kg. Keberadaan merkuri di air dan sedimen Sungai Batanghari dapat membuat biota pada air sungai tersebut ikut tercemar merkuri sehingga perlu mendapatkan perhatian agar pencemar yang berasal dari pertambangan emas tradisional dapat dicegah lebih lanjut sehingga dampak negatif pencemaran merkuri dapat diminimalisasi.

Dari hasil penelitian diatas, maka penelitian ini ingin membuktikan apakah benar adanya distribusi merkuri pada sungai Batanghari, dimana lokasi Olak Kemang menjadi Hulu dan Kemingking dalam menjadi Hilir pada penelitian ini. Olak Kemang dipilih dikarenakan terdapat industri tekstil di pinggir DAS tersebut sedangkan Kemingking Dalam dipilih dikarenakan adanya kegiatan pertanian yang menghasilkan merkuri dan sebagai titik hilir dari penelitian ini. Tetapi potensi sumber merkuri yang paling banyak yaitu dari kegiatan tambang emas (Pamungkas, 2015). Penelitian ini akan membuktikan apakah benar adanya distribusi merkuri pada sungai Batanghari dengan menganalisis logam merkuri pada daging kerang kepah yang ada di Olak Kemang dan Kemingking Dalam.

Kerang adalah salah satu biota air yang dapat dijadikan indikator tingkat pencemaran yang terjadi di dalam perairan (Samin, 2007). Kerang bersifat filter feeder, yang mendapatkan makanannya dengan cara menyaring air, dan memakan sedimen sehingga dapat mengakumulasi logam berat dalam jumlah yang tinggi (Ratnawati, 2008). Kerang Kepah (Polymesoda Erosa) adalah salah satu jenis kerang yang banyak ditemukan di sedimen sungai Batanghari. Dengan adanya resiko pencemaran pada air dan sedimen Sungai Batanghari oleh logam berat terutama merkuri yang dapat membahayakan bagi manusia jika mengkonsumsi kerang yang terakumulasi logam merkuri, maka perlu dilakukan penelitian terhadap kandungan merkuri (Hg) pada daging kerang kepah secara ICP (Inductively Coupled Plasma).

\section{Metode Penelitian}

Metode penelitian yang digunagan yaitu Destruksi Basah dengan menggunakan instrumen Inductively Coupled Plasma (ICP), pengambilan sampel kerang yang dilakukan dengan Purposive Sampling yaitu di Sungai Batanghari Olak Kemang dan Kemingking Dalam Kota Jambi.

a) Waktu dan Tempat Penelitian

Penelitian ini dilaksanakan pada Laboratorium Unit Pelaksana Teknis Daerah (UPTD) Balai Pengujian dan Sertifikasi Mutu Barang (BPSMB) dan Laboratorium Air Jurusan Teknik Lingkungan Universitas Andalas. Pengambilan sampel yang dilakukan di Sungai Batanghari Olak Kemang dan Kemingking Dalam Kota Jambi. Lama penelitian yaitu selama 5 bulan dimulai dari bulan Agustus 2020 hingga bulan Desember 2020. Lokasi penelitian dapat dilihat pada Gambar 1. 


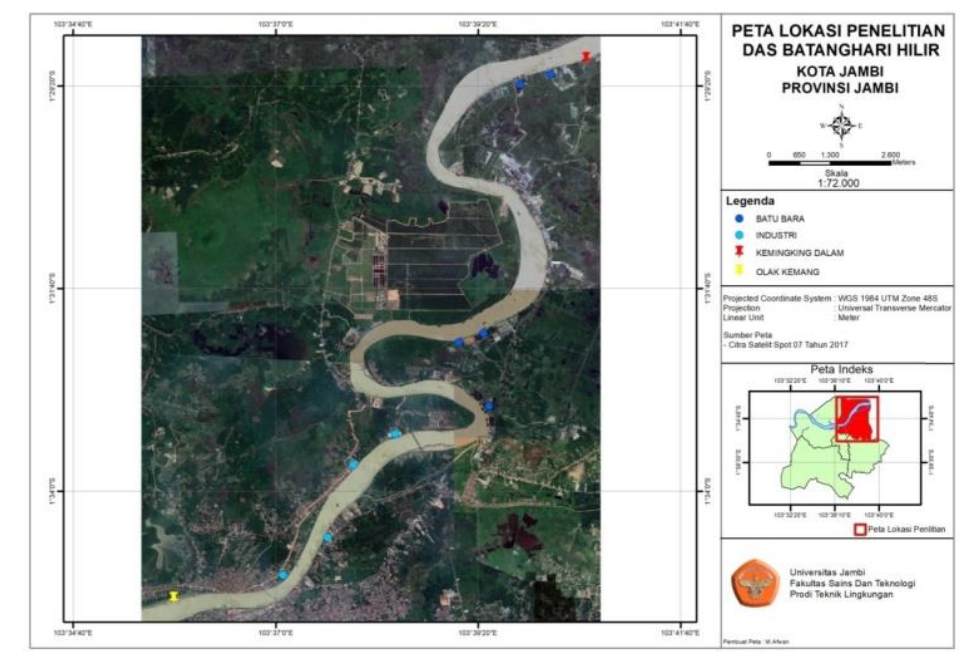

Gambar 1. Lokasi Penelitian

\section{b) Prosedur Penelitian}

1. Pemeriksaan sampel

Sampel dikeringkan dalam oven suhu $105^{\circ} \mathrm{C}$ selama $18-24$ jam, didinginkan dalam desikator selama 30 menit hingga mencapai suhu ruang, kemudian ditimbang bobotnya. Sampel dikeringkan lagi ke dalam oven Selama 30 menit, didinginkan dalam desikator selama 30 menit, lalu ditimbang bobotnya. Pengeringan diulangi hingga diperoleh bobot konstan (selisih penimbangan berturut-turut $0,2 \mathrm{mg}$ ).

2. Destruksi Sampel

Metode destruksi yang digunakan adalah cara basah. Sampel yang telah dihaluskan ditimbang sebanyak 5 gram dan dimasukkan dalam erlenmeyer lalu tambahkan $5 \mathrm{ml} \mathrm{HNO}$, pekat dan $1 \mathrm{ml}$ asam perklorat, didiamkan satu malam, esoknya dipanaskan pada suhu $100^{\circ} \mathrm{C}$ sampai $180^{\circ} \mathrm{C}$ selama 4 jam atau sampai uap kuningnya habis, dinginkan lalu tambahkan $3 \mathrm{ml} \mathrm{H} 2 \mathrm{O} 2$ dan panaskan lagi sekitar 15 menit dan dinginkan lagi, kemudian saring dan larutkan sampai tanda tera di labu ukur $10 \mathrm{ml}$, setelah itu saring dan pas kan kembali volumenya menjadi $50 \mathrm{ml}$ dengan aquadest.

3. Pengujian Inductively Coupled Plasma (ICP)

Pembuatan larutan standar 10 ppm sebanyak $0,25 \mathrm{~mL}, 0,5 \mathrm{~mL}, 0,75 \mathrm{~mL}$ dan $1 \mathrm{~mL}$ ke dalam 4 labu takar $50 \mathrm{~mL}$ yang berbeda. Larutan standar dengai berbagai konsentrasi tersebut kemudian diukur dengan Inductively Coupled Plasma. Sebelum menganalisis sampel, analisis standar pemeriksaan instrumen. Nilai konsentrasi diperoleh tidak boleh menyimpang dari nilai sebenarnya kurang lebih 5\% sehingga didapatkan kadar logam merkuri.

c) Teknik Analisis Data

Sampel yang telah kering dan dihaluskan menggunakan blender dihitung \% susut pengeringan. Rumus untuk perhitungan \% susut pengeringan adalah sebagai berikut:

$\%$ Susut pengeringan $=\frac{\mathrm{Bb}-\mathrm{Bk}}{\mathrm{Bb}} \times 100 \%$

keterangan:

$\mathrm{Bb}=$ Bobot basah sampel $(\mathrm{g})$

$\mathrm{Bk}=$ Bobot kering sampel $(\mathrm{g})$ 
Setelah menghitung \% susut pengeringan maka akan dihitung kadar logam berat dalam sampel bobot kering dan mendapatkan hasil logam berat pada sampel bobot kering. Jika telah mendapatkan hasil logam berat dalam sampel bobot kering maka akan dihitung kadar logam berat pada sampel bobot basah dikarenakan sampel awal yaitu daging kerang kepah dalam keadaan basah.

Kadar logam berat dalam sampel bobot kering dapat dihitung dengan menggunakan rumus sebagai berikut:

Kadar logam $(\mu \mathrm{g} / \mathrm{g}$ bobot kering $)=\frac{D}{W} \times \mathrm{V}$

keterangan:

$\mathrm{D}=$ Kadar sampel $(\mu \mathrm{g} / \mathrm{mL})$ dari hasil pembacaan ICP

$\mathrm{W}=$ Berat sampel kering $(\mathrm{g})$

$\mathrm{V}$ = Volume akhir larutan yang disiapkan $(\mathrm{mL})$

Untuk menghitung kadar logam dalam sampel bobot basah, digunakan rumus sebagai berikut (Sumarsono,1999):

Kadar logam $(\mu \mathrm{g} / \mathrm{g})=\frac{\text { Kadar sampel } \text { kering } x(100-\% \text { susut pengeringan })}{100} \ldots$

\section{Hasil Penelitian dan Pembahasan}

Tujuan penelitian ini yaitu untuk mengetahui ada atau tidaknya cemaran logam Merkuri ( $\mathrm{Hg})$ pada kerang kepah di perairan sungai Batanghari Olak Kemang dan Kemingking Dalam, kemudian menentukan kadar masing-masing logam sehingga dapat diketahui layak atau tidak layaknya kerang tersebut untuk dikonsumsi manusia. Kelayakan kerang kepah untuk dikonsumsi mengacu pada batas aman (batas maksimum cemaran) logam berat yang telah ditetapkan oleh ketentuan Standarisasi Nasional Indonesia (SNI) 7387 Tahun 2009 yang ditetapkan oleh Badan Standarisasi Nasional (BSN).

Kerang kepah yang digunakan sebagai sampel berukuran $5 \mathrm{~cm}-8 \mathrm{~cm}$ yang mana itu paling sering dikonsumsi masyarakat. Ukuran dinyatakan berdasarkan panjangnya cangkang. Dengan ukuran yang paling sering dikonsumsi masyarakat maka dapat dikatakan mewakili populasi kerang tersebut.

\section{Pembuatan kurva kalibrasi}

Pembuatan kurva kalibrasi dilakukan dari larutan induk dan dibuat 6 konsentrasi larutan. Larutan induk tersebut dibuat konsentrasi 0,$020 ; 0,040 ; 0,060 ; 0,080 ; 0,100 ; 0,120 \mathrm{ppm}$. Konsentrasi ini dipilih agar hasil serapan dapat mencakup hasil serapan sampel yang akan dianalisis. Hasil lengkapnya dapat dilihat pada Tabel 1.

Tabel 1. Absorbansi Larutan Standar Hg

\begin{tabular}{cc}
\hline Standar $\mathrm{mg} / \mathrm{L}$ & Absorban \\
\hline 0,000 & 0,00000 \\
0,020 & 0,01800 \\
0,040 & 0,03726 \\
0,060 & 0,05562 \\
0,080 & 0,07432 \\
0,100 & 0,09272 \\
0,120 & 0,11090 \\
\hline
\end{tabular}


Berdasarkan hasil absorbansi yang diperoleh seperti yang ditunjukkan pada Tabel 1. Dari data tersebut maka diperoleh grafik hubungan antara konsentrasi (sumbu X) dengan absorbansinya (Sumbu Y) yang menghasilkan regeresi linear seperti yang ditunjukkan pada Gambar 2.

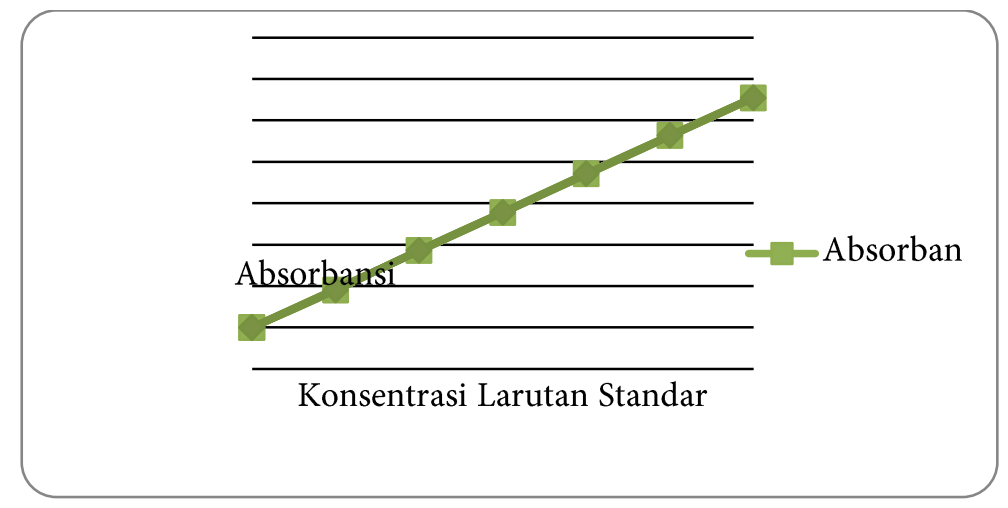

Gambar 2. Konsentrasi larutan standar Hg

Kurva larutan standar tersebut akan digunakan untuk menentukan konsentrasi sampel yang terukur sebenarnya dengan menggunakan persamaan regresi linear, yaitu $\mathrm{Y}=\mathrm{ax}+\mathrm{b}$, maka dipeoleh a (slope) $=0,92713$ dan $\mathrm{b}$ (intersep) $=0,00008$. Persamaan linear pada kurva standar merkuri $(\mathrm{Hg})$ adalah Y $=0,92713 \mathrm{x}-0,00008$, dimana $\mathrm{Y}$ adalah absorbansi dan $\mathrm{X}$ merupakan konsentrasi.

Berdasarkan persamaan yang diperoleh antara absorbansi dan larutan standar merkuri (Hg) yaitu y = $0,92713 \mathrm{x}-0,00008$ maka diperoleh hasil seperti ditunjukkan oleh Tabel 2 berikut.

Tabel 2. Hasil Konsentrasi Merkuri dalam Sampel

\begin{tabular}{ccc}
\hline No & $\mathrm{Y}$ & $\begin{array}{c}\mathrm{X} \\
(\mathrm{mg} / \mathrm{l})\end{array}$ \\
\hline 1 & & 0,02578 \\
2 & 0,02382 & 0,02457 \\
3 & 0,02270 & 0,02368 \\
4 & 0,02187 & 0,03481 \\
5 & 0,03219 & 0,03334 \\
6 & 0,03083 & 0,03362 \\
\hline
\end{tabular}

Berdasarkan Tabel 2. $\mathrm{Y}$ adalah nilai absorbansi sampel dan $\mathrm{X}$ adalah nilai kandungan kadar merkuri ( $\mathrm{Hg}$ ) dalam sampel. Setelah mendapatkan kadar merkuri dalam sampel maka akan dihitung kadar merkuri sampel dalam bobot kering. Hasil merkuri pada sampel daging kerang kepah dalam bobot kering dapat dilihat pada Tabel 3 .

Tabe1 3. Hasil Kadar Merkuri (Hg) dalam Sampel (bobot kering) (mg/Kg)

\begin{tabular}{cccccc}
\hline No & Sampel & $\begin{array}{c}\text { Konsentrasi Sampel } \\
(\mathrm{mg} / \mathrm{L})\end{array}$ & $\begin{array}{c}\text { Volume } \\
(\mathrm{mL})\end{array}$ & $\begin{array}{c}\text { Massa Sampel } \\
(\mathrm{g})\end{array}$ & $\begin{array}{c}\text { Bobot } \\
\text { Kering } \\
(\mathrm{mg} / \mathrm{Kg})\end{array}$ \\
\hline 1 & AD1 A & 0,02578 & 25 & 5,0026 & 0,129 \\
2 & AD1 B & 0,02457 & 25 & 5,1009 & 0,120 \\
3 & AD1 C & 0,02368 & 25 & 5,0293 & 0,118 \\
\hline
\end{tabular}




\begin{tabular}{cccccc}
\hline No & Sampel & $\begin{array}{c}\text { Konsentrasi Sampel } \\
(\mathrm{mg} / \mathrm{L})\end{array}$ & $\begin{array}{c}\text { Volume } \\
(\mathrm{mL})\end{array}$ & $\begin{array}{c}\text { Massa Sampel } \\
(\mathrm{g})\end{array}$ & $\begin{array}{c}\text { Bobot } \\
\text { Kering } \\
(\mathrm{mg} / \mathrm{Kg})\end{array}$ \\
\hline 4 & AD2 A & 0,03481 & 25 & 5,0128 & 0,174 \\
5 & AD2 B & 0,03334 & 25 & 5,0277 & 0,166 \\
6 & AD2 C & 0,03362 & 25 & 5,0093 & 0,168 \\
\hline
\end{tabular}

Berdasarkan hasil analisis kuantitatif pada Tabel 5, volume yang digunakan pada pengukuran kadar merkuri dalam daging kerang kepah yaitu $25 \mathrm{ml}$, sedangkan massa sampel dgunakan 5 gr dikarenakan prosedur destruksi basah menurut SNI 2354 Tahun 2011 mengatakan bahwa sampel yang akan didetruksi ditimbang seberat 5 gr. Keenam sampel positif mengandung merkuri dengan konsentrasi yang berbeda-beda. AD $1 \mathrm{~A}, \mathrm{AD} 1 \mathrm{~B}$, dan $\mathrm{AD} 1 \mathrm{C}$ merupakan sampel daging kerang kepah yang berlokasi di Olak Kemang dan AD 2 A, B C merupakan sampel yang berlokasi di Kemingking dalam. Hasil analisis pada sampel daging kerang kepah di Olak Kemang yaitu 0,129 mg/Kg; 0,120 mg/Kg; dan 0,118 mg/Kg sedangkan di Kemingking Dalam yaitu 0,174 mg/Kg; 0,166 mg/Kg; 0,168 mg/Kg.

\section{Hasil Analisis dan Batas Cemaran Logam Merkuri pada Pangan SNI 7387:2009}

Setelah mengetahui hasil kadar merkuri sampel dalam bobot kering maka, hasil sampel dlam bobot kering tersebut akan dikonversi ke data kadar merkuri pada sampel daging kerang kepah dengan dihitungnya bobot basahnya. Kadar merkuri pada sampel daging kerang kepah dalam bobot basah dapat dilihat pada Tabel 4.

Tabel 4. Kadar Merkuri Rata-rata dalam Bobot Basah

\begin{tabular}{lccccc}
\hline No & Sampel & $\begin{array}{c}\text { Bobot } \\
\text { Kering } \\
(\mathrm{mg} / \mathrm{Kg})\end{array}$ & $\begin{array}{c}\text { Susut } \\
\text { Pengeringan }(\%)\end{array}$ & $\begin{array}{c}\text { Bobot Basah } \\
(\mathrm{mg} / \mathrm{Kg})\end{array}$ & Rata-rata \\
\hline 1 & AD1 A & 0,129 & 61,50845985 & 0,050 & 0,042 \\
2 & AD1 B & 0,120 & 61,86537907 & 0,045 & \\
3 & AD1 C & 0,118 & 73,25447984 & 0,031 & 0,108 \\
\hline 4 & AD2 A & 0,174 & 52,91136493 & 0,081 & \\
5 & AD2 B & 0,166 & 46,21576751 & 0,089 & 0,155 \\
6 & AD2 C & 0,168 & 7,366847918 & 0,159 & \\
\hline
\end{tabular}

Dilihat dari Tabel 4 kadar merkuri pada daging kerang kepah di Kemingking Dalam adalah 0,108 $\mathrm{mg} / \mathrm{kg}$ sedangkan kadar merkuri pada daging kerang kepah di Olak Kemang yaitu 0,042 mg/kg. Kadar merkuri pada daging kerang kepah di Olak Kemang maupun Kemingking Dalam tidak melebihi SNI 7387:2009 tentang batas cemaran logam berat pada pangan yang mana nilai untuk merkuri pada kekerangan yaitu $1,0 \mathrm{mg} / \mathrm{kg}$.

\section{Perbandingan Kadar Logam Merkuri dari Hulu ke Hilir}

Uji Independent sampel T-Test dengan SPSS

Kadar Merkuri (Hg) dalam sampel daging kerang kepah pada Olak Kemang dibandingkan dengan Kemingking Dalam menggunakan Statistical Product and Service Solution (SPSS) dengan uji Independent Samples T-Test untuk mengetahui tingkan cemaran signifikan (nyata) atau tidak. 
Uji independen sampel T-test merupakan bagian dari statistik inferensial parametrik (Uji beda atau uji perbandingan). Pada penelitian ini uji sampel T-test dilakukan untuk mengetahui apakah ada perbedaan rata-rata hasil kadar merkuri pada daging kerang kepah di Olak Kemang dan Kemingking Dalam. Untuk mengetahui apakah ada perbedaan rata-rata hasil kadar Hg pada kerang kepah di Olak Kemang dan Kemingking Dalam. Hasil uji SPSS dapat dilihat pada Tabel 5.

Tabel 5. Group Statistics SPSS

\begin{tabular}{llcccc}
\hline No & Lokasi & N & Mean & $\begin{array}{c}\text { Std. } \\
\text { Deviation }\end{array}$ & $\begin{array}{c}\text { Std. Error } \\
\text { Mean }\end{array}$ \\
\hline 1 & Olak Kemang & 3 & 0,0633 & 0,007638 & 0,004410 \\
& & & 3 & & \\
2 & Kemingking & 3 & 0,1036 & 0,031786 & 0,018352 \\
& Dalam & & 7 & & \\
\hline
\end{tabular}

Berdasarkan tabel Output "Group Statistics" di atas diketahui jumlah data hasil Olak Kemang sebanyak 3 data, sementara untuk Kemingking Dalam sebanyak 3 data juga. Nilai rata-rata kadar Hg Kerang atau Mean untuk Olak Kemang 0,06333, sementara untuk Kemingking Dalam adalah 0,10367. Dengan demikian secara deskriptif statistik dapat disimpulkan ada perbedaan rata-rata hasil kadar $\mathrm{Hg}$ pada kerang di Olak Kemang dan Kemingking Dalam. Selanjutnya untuk membuktikan apakah perbedaan tersebut signifikan atau tidak maka kita perlu menafsirkan Output "Independent Samples Test".

\section{Kesimpulan}

Kesimpulan yang ditemukan berdasarkan hasil penelitian ini antara lain:

1. Kadar kandungan merkuri $(\mathrm{Hg})$ pada daging kerang kepah di perairan sungai Batanghari tepatnya di Olak Kemang yaitu 0,050;0,045;0,031 mg/kg dan dirata-ratakan menjadi $0,042 \mathrm{mg} / \mathrm{kg}$ sedangkan kadar merkuri $(\mathrm{Hg})$ pada daging kerang kepah di perairan sungai Batanghari yang bertempatan pada Kemingking Dalam yaitu 0,$081 ; 0,089 ; 0,155 \mathrm{mg} / \mathrm{kg}$ yang dirata-ratakan menjadi $0,108 \mathrm{mg} / \mathrm{kg}$.

2. Kadar kandungan merkuri $(\mathrm{Hg})$ pada kerang kepah di perairan sungai Batanghari baik Olak Kemang maupun Kemingking Dalam tidak melebihi SNI 7387:2009 tentang batas maksimum cemaran logam dalam pangan khususnya untuk merkuri untuk kekerangan yaitu $1,0 \mathrm{mg} / \mathrm{kg}$ sedangkan kadar merkuri ( $\mathrm{Hg}$ ) pada daging kerang kepah di Olak Kemang rata-rata yaitu 0,042 $\mathrm{mg} / \mathrm{kg}$ dan Kemingking Dalam sebesar 0,108 mg/kg.

3. Perbedaan kadar merkuri (Hg) pada daging kerang kepah di Olak Kemang (hulu) dan Kemingking Dalam (hilir) yaitu signifikan dapat dilihat dari hasil uji SPSS Independent Samples Test.

\section{Daftar Pustaka}

[1] Afwan, M. (2021). Analisis Tingkat Cemaran Logam Timbal (Pb) pada Kerang Kepah (Polymesoda erosa) di Perairan Sungai Batanghari Kota Jambi. Jambi : Universitas Jambi.

[2] Astawan, M. (2008). Bahaya Logam Berat Dalam Makanan. 29 Agustus 2020. http://ecoton.or.id/tulisanlengkap.php?id=1300 
[3] Dewi.(2009). Mengenal Pencemaran Sungai. Semarang. Badan Pengelola MIPA-UNDIP, 55-64

[4] Fadhilah A. (2016). Karakteristik Asam Lemak Daging Keong Macan, Kerang Tahu, dan Kerang Salju. Institut Pertanian Bogor. Bogor.

[5] Gusanti, Rizki. (2021). Analisis Parameter Fisika dan Kimia serta Strategi Pengendalian Pencemaran Sungai Sub DAS Batanghari Hilir Kota Jambi. Jambi : Universitas Jambi.

[6] Kumalawati.(2016). Analisis kandungan logam $C d, C u$, dan $\mathrm{Pb}$ dalam salah satu produk ikan tuna kaleng secara spektrofotometri serapan atom.Jakarta: Fakultas Farmasi Universitas Pancasila.

[7] Kristianingrum, S. (2012). Kajian Berbagai Proses Destruksi Sampel dan Efeknya. Seminar Nasional Penelitian, Pendidikan Dan Penerapan MIPA, 2(3), 195-202.

[8] Nurventi, N. (2019). Perbandingan Metode Analisis Logam Berat Kromium dan Timbal Menggunakan Inductively Coupled Plasma Optical Emision Spectroscopy (ICP OES) dan Atomic Absorbtion Spectrometry (AAS). In Central Library Of Maulana Malik Ibrahim State Islam University Of Malang. Universitas Islam Negeri Maulan Malik Ibrahim.

[9] Marrieta College. (2009). Anatomy Of Bivalve : Adductor Muscle. 30 Agustus 2020. www.marietta.edu/ biol/mussels/2.html

[10] Martono, J., Peranginangin. R. (2006). Kandungan Logam Berat pada Kerang Kepah dan Air Laut di Perairan Banjarmasin. Jurnal perikanan VII no. 2 177-184

[11] Purnomo, A.D., Suratman, S. (2013). Analisis Kandungan Logam Timbal (Pb) dan Laju Konsumsi Aman Kerang Kepaj di Sungai Donan Cilacap. Kesmas Indonesia. 6, 85-93

[12] Peraturan Pemerintah Nomor 82 Tahun 2001 Tentang Pengelolaan Kualitas Air dan Pengendalian Pencemaran Air, 14 Desember 2001.

[13] Peraturan Pemerintah Nomor 57 Tahun 2016 Tentang Perubahan Atas Pemerintah Nomor 71 Tahun 2015 Perlindungan dan Pengelolaan Ekosistem Gambut.

[14] Ratnaningsih, S. (2013). Mengenal Pencemaran Ragam Logam. Graha Ilmi, Yogyakarta. ISBN: 978-602-262-089-1

[15] Ratnawati, E. (2008). Penentuan Kandungan Logam pada Kerang Lijau dengan Metode Analisis Aktiv Asi Neutron Komparatif. Prosiding Seminar Nasional Penelitian dan Pengelolaan Perangkat Nuklir Pusat Teknologi Akselerator dan Proses Bahan. Yogyakarta, 30 Agustus 2020.

[16] Romimohtarto, K. (2007). Kualitas air dalam budidaya sungai. 29 Agustus 2020. http://masantos.wordpress.com/category/biologi-laut

[17] Salim, I. (2016). Sumber daya hayati moluska kerangMytilidae. Laboratorium Manajemen Sumberdaya Perikanan. Manajemen Sumbersaya Perairan. Fakultas Perikanan dan Ilmu Kelautan. Institut Pertanian Bogor.

[18] Samin, Supriyanto, dan Kamal, Z. (2007). Analisis cemaran logam berat $\mathrm{Pb}, \mathrm{Cu}$, dan $\mathrm{Cd}$ pada ikan air tawar dengan metode spektrometri nyala serapan atom (SSA). ISSN 1978-0176. Sem, Nas. IIISDM Teknologi Nuklir, 147-152

[19] Saputra, N.A . (2018). Konsentrasi Logam Berat (Cd dan Pb) pada Sedimen Permukaan Perairan Teluk Bayur Provinsi Sumatera Barat Indonesia. J. Ilmu Lingkungan. 3. 
[20] Simanullang, Yusni. (2018). Studi Kelimpahan dan Pola Pertumbuhan Kerang Kepah (Meretrix meretrix) di Perairan Estuari Suaka Margasatwa Karang Gading Kabupaten Deli Serdang. Fakultas Pertanian : Universitas Sumatera Utara

[21] Subanri. (2008). Kajiann Beban Pencemaran Merkuri (Hg) terhadap Air Sunggai Menyuke dan Gangguan Kesehatan pada Penambang sebagau Akibat Penambangan Emas tanpa Izin (Peti) di Kecamatan Menyuke Kabupaten Landak Kalimantan Barat. Universitas Diponegoro. https://core.ac.uk/download/pdf/11723074.pdf

[22] Standar Nasional Indonesia 7387: 2009 tentang Batas maksimum cemaran logam berat dalam pangan

[23] Undang-Undang (UU) Nomor 11 Tahun 2017 Tentang Pengesahan Minamata Convention On Mercury (Konversi Minamata mengenai Merkuri).

[24] Wahyono, S. (2008). Pencemaran Lingkungan Mengancam Keamanan Pangan. Sulawesi Selatan. ISSN 1411-1674-J. Sci. Technol., Vol. 2, 35-44.

[25] Widodo, W., Sastiono, A., Rumampuk, R. J. (2008). Efek Toksik Logam Pencegahan dan Penanggulangan Pencmaran. Yogyakarta: penerbit Andi Yogyakarta

[26] Yanti, Etty. (2010). Kontaminasi Merkuri (Hg) dalam Organ Tubuh Ikan Petek di Perairan Ancol, Teluk Jakarta. Institut Pertanian Bogor : Bogor

[27] Yusni, P. A. R. (2018). Analisis Kadar Logam Merkuri (Hg) dan (pH) Air Sungai Kuantan Terdampak Penambangan Emas Tanpa Izin (PETI). Orbital: Jurnal Pendidikan Kimia, 2(1), 2836. https://doi.org/10.19109/ojpk.v2i1.2167 